\title{
New records of Pristimantis carranguerorum (Anura: Craugastoridae) from the Cordillera Oriental of Colombia
}

\author{
Marvin Anganoy-Criollo ${ }^{1,3}$ \& Juan P. Ramírez ${ }^{2}$ \\ ${ }^{1}$ Laboratorio de Anfibios, Grupo Cladística Profunda y Biogeografía Histórica, Instituto de Ciencias Naturales, Universidad Nacional de \\ Colombia, Bogotá, Colombia \\ ${ }^{2}$ Museo de Historia Natural ANDES and Laboratorio Biomics, Departamento de Ciencias Biológicas, Facultad de Ciencias, Universidad de \\ los Andes, Apartado Aéreo 4976, Bogotá, Colombia \\ ${ }^{3}$ Corresponding author. E-mail: marvinanganoy@gmail.com
}

\begin{abstract}
Pristimantis carranguerorum (Lynch, 1994) is a poorly-known species of frog, endemic to the eastern slopes of the Cordillera Oriental of Colombia, which is known only from a few localities in the Boyacá and Casanare departments. Herein, we provide the first records of this species from Cundinamarca Department; these are the southernmost and highest altitude records for this species. We summarize the distribution of this species based on all known records and including additional unreported localities from Boyacá and Cundinamarca departments.
\end{abstract}

Key words. Terrarana; direct-developing frogs; range extension; endemism; Cundinamarca

Pristimantis carrangerorum (Lynch, 1994) is a species of direct-developing frog endemic to Colombia. It is categorized as Vulnerable by the Red Book of Colombian Amphibians (RENJIFo 2004) and as Data Deficient by the IUCN Red List (CASTRO et al. 2004). This species was described by LYNCH (1994) and assigned to the "Eleutherodactylus" (now genus Pristimantis) conspicillatus species group, in which it has remained to date. Currently, $P$. carrangerorum is known from its original description (LYNCH 1994), an account in the Red Book of Colombian Amphibians (RENIJFo 2004), and its inclusion in several regional and national checklists (e.g., Acosta-Galvis 2000, Bernal \& LynCH 2008, Acosta-Galvis \& Alfaro-Bejarano 2011). Pristimantis carrangerorum has not been included in any of the published phylogenies of the genus (e.g., Hedges et al. 2008, Pinto-SÁnchez et al. 2012, PADiAl et al. 2014).

Pristimantis carranguerorum was described based on specimens from several sites between 1350-2060 m above sea level (a.s.l.) in Pajarito Municipality, Boyacá Department, all located on the eastern flank of the Cordillera Oriental of Colombia. Acosta-Galvis \& Cuentas (2016) provided a distribution map incorporating several new localities in Boyacá Department, north of the type locality, but without providing any supporting evidence of these new records. In 2011, this species was reported for the first time from Casanare Department by ACOSTA-GALvis \& Alfaro-Bejarano (2011), although they also did not specify localities or vouchers that support this range extension. Later, PEDROZA-BANDA et al. (2014) reported this species based on 1 specimen collected in Aguazul municipality, Casanare Department, at 738 m a.s.1., which is the lowest known record of the species.

Between late January and early February 2016, we recorded P. carranguerorum at 3 localities during a field trip conducted at Vereda San Antonio, Junín municipality, Cundinamarca Department, between 2650-2802 m a.s.1. (Finca La Cabaña: 044ㄴㄷㄴ $14.5^{\prime \prime} \mathrm{N}, 073^{\circ} 39^{\prime} 52.3^{\prime \prime} \mathrm{W}$; Finca El Páramo: 0445'29.9" N, 07340'11.9" W; and Finca Peña Colorada: 0444'43.2" N, $073^{\circ} 39^{\prime} 49^{\prime \prime} \mathrm{W}$; Table 1). Fourteen specimens were found near rivulets covered by small remnants of gallery forest. Individuals were found during the day on the leaf litter of forest, whereas at night, specimens were found on leaves at 5-45 cm above the ground. The specimens were collected with the authorization of Autoridad Nacional de Licencias Ambientales (ANLA), Ministerio de Ambiente of Colombia, resolution number 0315, 29 March 2016. These specimens were deposited in the collection of the Laboratorio de Anfibios, Instituto de Ciencias Naturales, Universidad Nacional de Colombia, Bogotá, Colombia (ICN) (ICN 55896-55909).

Additionally, 23 specimens of $P$. carranguerorum collected at 5 previously unreported localities in Boyacá and Cundinamarca departments (Table 1, Fig. 1) were also found in ICN.

The specimens reported in this work are identified as $P$. carranguerorum by the following external morphological characters (LYNCH 1994): venter nearly smooth to weakly areolate, short dorsolateral folds in scapular region, snout obtuse in dorsal view and rounded in lateral view (Fig. 2; ICN 55897), distinct tubercles on the eyelid absent (Fig. 2) (except in a few juveniles from Junín municipality, Finger I slightly shorter than Finger II, enlarged discs on the Fingers III-IV, fingers and toes with fleshy lateral keels, absence of ulnar tubercles, small non-conical tubercles on heel (Fig. 2), short inner tarsal fold, and a short Toe $\mathrm{V}$ that does not reach the distal subarticular 
Table 1. List of all known specimens of Pristimantis carranguerorum (Lynch, 1994) separated by locality. All vouchers are deposited in the ICN collection, including the uncatalogued specimen with field number TAS (Teddy Angarita-Sierra) 894.

\begin{tabular}{|c|c|c|c|c|c|c|c|}
\hline $\begin{array}{l}\text { Locality no. } \\
\text { (in map) }\end{array}$ & Museum voucher & Department & Municipality & $\begin{array}{l}\text { Latitude } \\
\text { (N) }\end{array}$ & $\begin{array}{l}\text { Longitude } \\
\text { (W) }\end{array}$ & $\begin{array}{l}\text { Elevation } \\
\quad(\mathbf{m})\end{array}$ & Source \\
\hline 1 & ICN 5345-9, 5251-60, 5361-3 & Boyacá & Pajarito & $05^{\circ} 26^{\prime} 35^{\prime \prime}$ & $072^{\circ} 43^{\prime} 43^{\prime \prime}$ & 1600 & LYNCH 1994 \\
\hline 2 & ICN 5128, 5130, 5132, 5135, 5139, 5145, 5351-7, 5360-1 & Boyacá & Pajarito & $05^{\circ} 24^{\prime} 30.0^{\prime \prime}$ & $072^{\circ} 43^{\prime} 06.8^{\prime \prime}$ & 1600 & LYNCH 1994 \\
\hline 3 & ICN $5601-3,7166-71$ & Boyacá & Pajarito & $05^{\circ} 25^{\prime} 54^{\prime \prime}$ & $072^{\circ} 42^{\prime} 09^{\prime \prime}$ & $2015-2060$ & LYNCH 1994 \\
\hline 4 & ICN 9402-32, 9439-9468, 9470 & Boyacá & Pajarito & $05^{\circ} 17^{\prime} 00^{\prime \prime}$ & $072^{\circ} 42^{\prime} 00^{\prime \prime}$ & $1600-1650$ & LYNCH 1994 \\
\hline 5 & ICN 9433-7 & Boyacá & Pajarito & $05^{\circ} 17^{\prime} 38.4^{\prime \prime}$ & $072^{\circ} 42^{\prime} 21.6^{\prime \prime}$ & 1600 & LYNCH 1994 \\
\hline 6 & $\begin{array}{l}\text { ICN 44956-7, 44966, 44975, 44977, 44981,44983, } \\
44985-6,44995,45005,45009\end{array}$ & Boyacá & Santa María & $04^{\circ} 53^{\prime} 38.8^{\prime \prime}$ & $073^{\circ} 16^{\prime} 56.5^{\prime \prime}$ & $1080-1180$ & This work \\
\hline 7 & ICN 44959, 44989-90, 45013-5, 45024, 45137 & Boyacá & Santa María & $04^{\circ} 53^{\prime} 37.9^{\prime \prime}$ & $073^{\circ} 14^{\prime} 57.1^{\prime \prime}$ & $1200-1380$ & This work \\
\hline 8 & ICN 45139 & Boyacá & Santa María & $04^{\circ} 50^{\prime} 53.7^{\prime \prime}$ & $073^{\circ} 16^{\prime} 20.7^{\prime \prime}$ & 900 & This work \\
\hline 9 & ICN (TAS 894) & Casanare & Aguazul & $05^{\circ} 14^{\prime} 01.6^{\prime \prime}$ & $072^{\circ} 40^{\prime} 17.9^{\prime \prime}$ & 738 & PEDROZA-BANDA et al. 2014 \\
\hline 10 & ICN 40931 & Cundinamarca & Ubalá & $04^{\circ} 45^{\prime} 19^{\prime \prime}$ & $073^{\circ} 21^{\prime} 10^{\prime \prime}$ & 1500 & This work \\
\hline 11 & ICN 40978 & Cundinamarca & Ubalá & $04^{\circ} 42^{\prime} 16.5^{\prime \prime}$ & $073^{\circ} 21^{\prime} 52.5^{\prime \prime}$ & 1000 & This work \\
\hline 12 & ICN 55905-9 & Cundinamarca & Junín & $04^{\circ} 45^{\prime} 14.5^{\prime \prime}$ & $073^{\circ} 39^{\prime} 52.3^{\prime \prime}$ & 2650 & This work \\
\hline 13 & ICN 55899-904 & Cundinamarca & Junín & $04^{\circ} 45^{\prime} 29.9^{\prime \prime}$ & $073^{\circ} 40^{\prime} 11.9^{\prime \prime}$ & 2688 & This work \\
\hline 14 & ICN 55896-8 & Cundinamarca & Junín & $04^{\circ} 44^{\prime} 43.2^{\prime \prime}$ & $073^{\circ} 39^{\prime} 49.4^{\prime \prime}$ & 2802 & This work \\
\hline
\end{tabular}

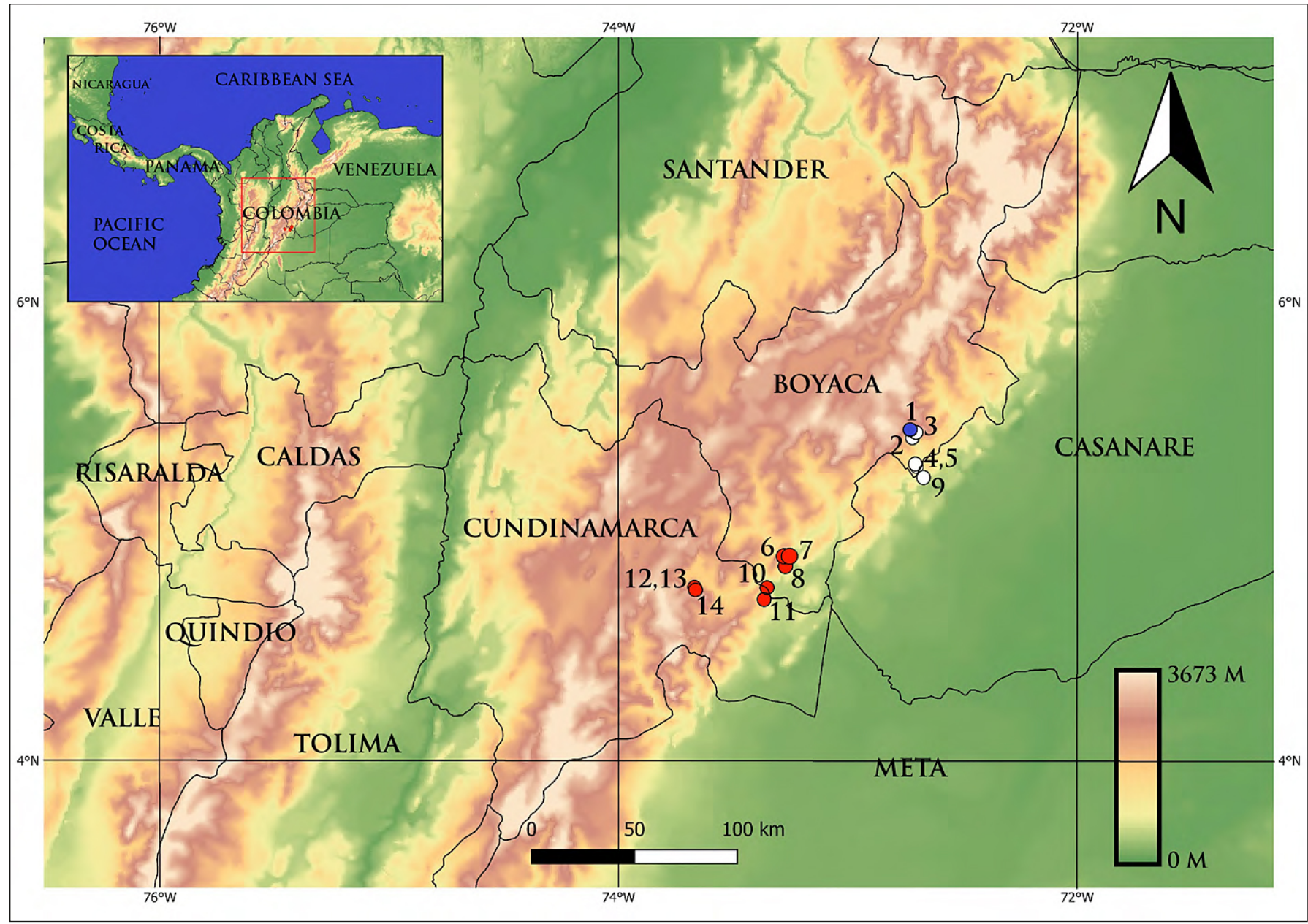

Figure 1. Distribution map of Pristimantis carranguerorum. Red dots correspond to the new localities reported by the present work, white dots refer to the literature records, and the blue dot to the type locality. Each number corresponds to one of the localities referred to in Table 1. The inset map indicates the location of the data points in northwestern South America. The datum used in this map is WGS84.

tubercle of Toe IV.

Coloration of all the specimens reported herein is also similar to the type series of $P$. carranguerorum. The specimens have gray to brown dorsum with darker markings, including dark brown labial and oblique limb bars, as well as a canthal and a supratympanic stripe (Fig. 2). The specimens from
Junín municipality and the type locality have a copper iris in life with brown reticle (Fig. 2; LYNCH 1994), but the color of the iris from the other known specimens is unknown, as this coloration did not persist after preservation. The Junín vouchers are unusual as they have pale spots in the posterior part of the thighs, whereas the specimens of Santa María municipality 


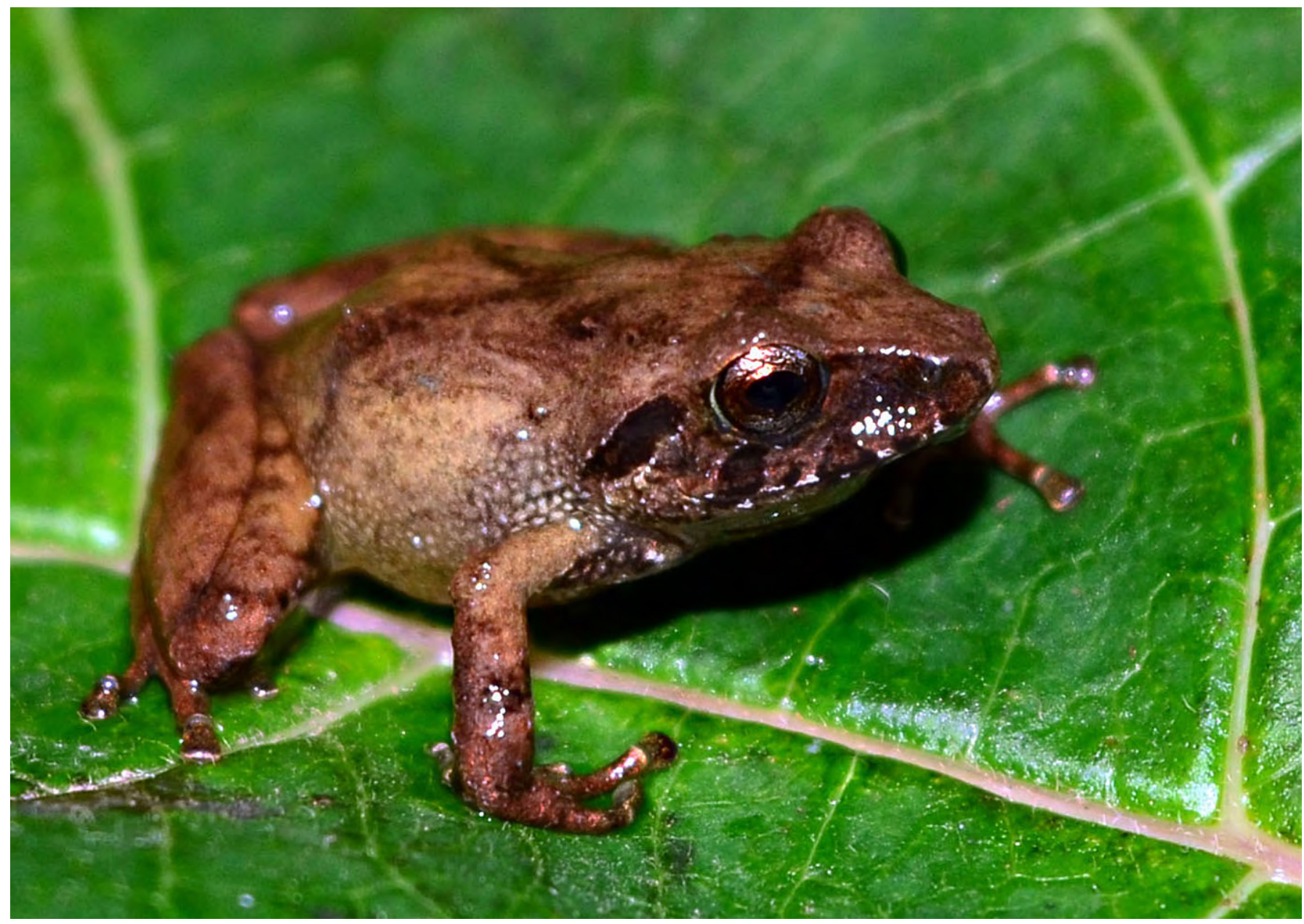

Figure 2. A juvenile female of Pristimantis carranguerorum from Junín, Cundinamarca (ICN 55897) with snout-vent length (SVL) of $16.8 \mathrm{~mm}$.

have a cream coloration in the posterior part of the thigh with brown stippling. These coloration patterns are different from the other known specimens of $P$. carranguerorum in which the posterior part of the thighs is uniform brown ( $\mathrm{LYNCH} 1994)$. Furthermore, Junín specimens have dark brown spots on their venter, which were generally much more numerous in the throat. Some specimens, specifically ICN 55901-2, 55905-7, and 55909, have a brown throat with pale mottling, in contrast to the stippled venter (although also with a more heavily marked throat) found in Santa María specimens, as well as in the type series (according to LYNCH 1994).

The identification of most of the specimens reported in this work was corroborated by John D. Lynch, Sandy B. Arroyo, and Gustavo González, experts on the taxonomy of the genus Pristimantis of Colombia. Additionally, all the newly-reported specimens were compared directly with the type series of $P$. carranguerorum.

The newly collected specimens of $P$. carranguerorum from Vereda San Antonio, Junín municipality, represent the first record of this species in the Cundinamarca Department and an extension to the distribution by ca. $120 \mathrm{~km}$ (in straight line) to the south (Fig. 1). This new locality also extends $742 \mathrm{~m}$ higher the altitudinal range of $P$. carranguerorum, from 2060 $\mathrm{m}$ to $2802 \mathrm{~m}$ a.s.l. Also, the previously unreported specimens provide additional records from Cundinamarca and Boyacá departments and fill the gap between the distribution of this species as previously known.

Although LyNCH (1994) suggested that the range of P. carranguerorum extends to the north of the type locality (Pajarito, Boyacá), the new records reported herein show that the range of the species comprises the eastern slope of the Cordillera Oriental to the south of Pajarito municipality, in Cundinamarca, Boyacá and Casanare departments, between 738 and $2802 \mathrm{~m}$ a.s.l. This latitudinal range is also exhibited by Pristimantis medemi (Lynch, 1994) and P. savagei (Pyburn \& Lynch, 1981) (Malambo-L. \& Marín-V. 2006, Acosta-Galvis 2015, Frost 2016), 2 species morphologically very similar to $P$. carranguerorum (LYNCH 1994). However, at the present time it is unknown if the distribution of any of these 3 species extends north of Pajarito due to the apparent absence of collections undertaken on those areas (pers. obs.). Thus, further studies are needed for a better understanding of the distribution of $P$. carranguerorum, as well as for researching other aspects of its biology that remain poorly known, such as its microhabitat use, call, diet, reproduction patterns, and phylogenetic relationships. Additionally, the conservation status of this species needs to be re-evaluated, given that the records presented in this publication extend considerably its known range.

\section{ACKNOWLEDGEMENTS}

We want to thank Dr. John D. Lynch for allowing access to the amphibian collection of the Universidad Nacional de Colom- 
bia, and by sharing his extensive knowledge of Pristimantis. MAA is grateful to Camilo Cortés by the invitation to be part of the project "Conservación, restauración y uso sostenible de servicios ecosistémicos entre los páramos Chingaza, Sumapaz, Guerrero, Cerros Orientales y su área de influencia". Also, we are grateful to Dora E. Jiménez and her family by their hospitality and collaboration in the field. Special thanks are also to Viviana Gutiérrez by her company to MAA in the field trips, and for daily support.

\section{LITERATURE CITED}

Acosta-Galvis, A.R. 2000. Lista de las ranas, salamandras y caecilias (Tetrapoda: Amphibia) de Colombia. Biota Colombiana 1: 289-319.

Acosta-Galvis, A.R. 2015. Una nueva especie del género Pristimantis (Anura: Craugastoridae) del complejo de páramos MerchánIguaque (Boyacá, Colombia). Biota Colombiana 16: 107-127.

Acosta-Galvis, A.R. \& D. Cuentas 2016. Lista de los anfibios de Colombia: referencia en línea, version 05.2015.0. Batrachia, Villa de Leyva, Boyacá, Colombia. Accessed at http://www.batrachia. com, 27 July 2016

Acosta-Galvis, A.R. and J.P. Alfaro Vejarano. 2011. Anfibios del Casanare; pp. 134-147, in: Usma, J.S., F. Trujillo \& L.T. Ayala (eds.). Biodiversidad del Casanare: ecosistemas estratégicos del departamento. Bogotá: Gobernación de Casanare / WWF Colombia, Bogotá.

BERNAL, M.H. \& J.D. LYNCH. 2008. Review and analysis of altitudinal distribution of the Andean anurans in Colombia. Zootaxa 1826: 1-25. https://doi.org/10.11646/zootaxa.1826.1.1

Castro, F., M. I. Herrera \& J. V. Rueda. 2004. Pristimantis carranguerorum. The IUCN Red List of threatened species 2004: e.T56495A11475448. https://doi.org/10.2305/iucn.uk.2004.rlts.t56 495al1475448.en. Downloaded on 16 March 2017.

Frost, D.R. 2016. Amphibian species of the world: an online reference. Version 6.0. New York: American Museum of Natural History. Accessed at http://research.amnh.org/herpetology/amphibia/index. html, 17 July 2016.
Hedges, S.B., W.E. Duellman \& M.P. Heinicke. 2008. New World direct-developing frogs (Anura: Terrarana): molecular phylogeny, classification, biogeography, and conservation. Zootaxa 1737: 1-182.

LyNCH, J.D. 1994. Two new species of the Eleutherodactylus conspicillatus group (Amphibia: Leptodactylidae) from the Cordillera Oriental of Colombia. Revista de la Academia Colombiana de Ciencias Exactas, Físicas y Naturales 19(72): 187-193.

Malambo-L., C. \& A. Marín-V. 2006. Geographic distribution: Eleutherodactylus medemi. Herpetological Review 37: 487.

Padial, J.M., T. Grant \& D.R. Frost. 2014. Molecular systematics of terraranas (Anura: Brachycephaloidea) with an assessment of the effects of alignment and optimality criteria. Zootaxa 3825: 1-132. https://doi.org/10.11646/zootaxa.3825.1.1

Pedroza-Banda, R., J. J. Ospina-Sarria, T. Angarita-Sierra, M. AngANOY-Criollo \& J.D. Lynch. 2014. Estado del conocimiento de la fauna de anfibios y reptiles del departamento de Casanare, Colombia. Revista de la Academia Colombiana de Ciencias Exactas, Físicas y Naturales 38(146): 17-34.

Pinto-Sánchez, N.R., R. Ibañez, S. Madriñan, O.I. Sanjur, E. Bermingham, \& A.J. Crawford. 2012. The great American biotic interchange in frogs: multiple and early colonization of Central America by the South American genus Pristimantis (Anura: Craugastoridae). Molecular Phylogenetics and Evolution 62: 954-972. https://doi.org/10.1016/j.ympev.2011.11.022

RENJIFo J.M. 2004. Rana de lluvia carranguera Eleutherodactylus carranguerorum; pp. 318-321 in: RUEDA-ALmONACID, J. V., J.D. LyNCH \& A. AmÉzQuita (eds.). Libro Rojo de los anfibios de Colombia. Serie Libros Rojos de Especies Amenazadas de Colombia. Bogotá: Conservación Internacional Colombia / Ministerio de Ambiente, Vivienda y Desarrollo Territorial.

Authors' contributions: MAA collected and examined the Junín specimens, and prepared the figures. JPR made the map and revised all specimens. Both authors wrote the manuscript.

Received: 17 December 2017

Accepted: 29 April 2017

Academic editor: Natan Medeiros Maciel 